\title{
Smart Water Management Framework Berbasis IoT Untuk Mendukung Pertanian Urban
}

\author{
Yan Mitha Djaksana ${ }^{1,2}$; Heru Sukoco ${ }^{3}$; Sri Wahjuni ${ }^{4}$; Hendra Rahmawan ${ }^{5}$; Shelvie Nidya Neyman \\ 1,3, 4, 5, 6 Department of Computer Science, Bogor Agricultural University, Indonesia \\ ${ }^{2}$ STMIK Eresha \\ ${ }^{1}$ yanmithadjaksana@apps.ipb.ac.id \\ ${ }^{3}$ hsrkom@ipb.ac.id \\ ${ }^{4}$ my_juni04@apps.ipb.ac.id \\ ${ }^{5}$ hrahmawan@apps.ipb.ac.id \\ ${ }^{6}$ shelvie@apps.ipb.ac.id
}

\begin{abstract}
Related to water resources is one of the problems that often occurs in certain areas that have large populations such as urban areas, in addition to having to provide water that is used for daily activities, today many urban residents live in urban hardships, so an alternative is needed in providing resources water that must be purchased in daily necessities, in this paper we proposed a framework for support urban farming that we called the smart water management system by utilizing the IoT (Internet of Thinks) technology specifically sensors and machine learning algorithms in managing available water resources. many researchers have developed a similar model, but the framework model that we proposed using reuse water and filtered rainwater so that it meets the minimum quality requirements of water that can be reused in agriculture, so we hopes to make domestic water use more effective and efficient and predictable water consumption and availability.
\end{abstract}

Keywords: Smart, Water, Management System, IoT, urban farming

\begin{abstract}
ABSTRAK
Ketersediaan sumber daya air merupakan salah satu masalah yang sering dihadapi khususnya di daerah yang memiliki kepadatan penduduk yang tinggi seperti daerah perkotaan, selain harus menyediakan air yang digunakan kegiatan sehari hari, dewasa ini banyak penduduk urban mencoba untuk melaksanakan pertanian urban untuk memenuhi kebutuhan dasar kehidupannya ditengah kerasnya hidup di perkotaan, sehingga diperlukan alternatif dalam menyediakan sumber daya air yang pastinya harus dibeli dalam memenuhi kebutuhan sehari-harinya, pada paper ini penulis mencoba menawarkan kerangka kerja cerdas dalam pengelolaan air khususnya untuk membantu kebutuhan pertanian urban, kerangka kerja ini terdiri dari lima layer yang disebut dengan smart water management system dengan memanfaatkan teknologi IoT(Internet of Thinks) khususnya sensor dan algoritma machine learning dalam mengelola sumber daya air yang tersedia, banyak peneliti sudah mengembangkan model serupa, tapi model kerangka kerja yang penulis kembangkan menambahkan penggunaan air limbah rumah tangga dan air hujan yang difilterisasi sehinga memenuhi kebutuhan minimal kualitas air yang dapat digunakan kembali dalam pertanian, sehingga harapannya dapat membuat penggunaan air rumah tangga lebih efektif dan efisien serta dapat diprediksi konsumsi dan ketersediaan air.
\end{abstract}

Kata kunci: Smart, Water, Management System, IoT, urban farming 


\section{PENDAHULUAN}

Dengan pesatnya pertumbuhan penduduk di dunia, dan khususnya di Indonesia membuat peningkatan kebutuhan terhadap makanan dan minuman ikut meningkat saat ini jumlah penduduk Indonesia telah mencapai lebih dari 260 juta dan tentunya terus akan meningkat dalam jangka waktu kedepan, dengan meningkatnya jumlah penduduk perlu adanya persiapan yang matang untuk menunjang segala kebutuhan terutama di daerah urban yang memiliki kepadatan penduduk yang sangat tinggi sehingga lahan yang dimiki tentunya sangat terbatas baik yang digunakan untuk kegiatan sehari-hari maupun untuk menghasilkan sumber makanan dan pertanian yang sering disebut dengan istilah Urban Farming, melakukan kegiatan pertanian di daerah urban memiliki berbagai tantangan salah satunya penyediaan air untuk mendukung kegiatan pertanian tersebut, seperti yang kita ketahui air adalah kebutuhan pokok manusia dengan kapasitas yang terbatas penggunaan air untuk kehidupan sehari-hari seperti minum, mandi dan mencuci menjadi kebutuhan yang tidak bisa digantikan sehingga perlu adanya teknologi yang bisa menjamin kesediaan air bersih tetap terjaga dan dapat juga dimanfaatkan untuk kegiatan pertanian di daerah urban atau urban farming,

Dengan pengembangan teknologi IoT (Internet Of Think) dapat menjadi solusi dalam menyediakan air yang dapat digunakan untuk pertanian urban tetapi tidak mengganggu kebutuhan air untuk kehidupan sehari-hari di wilayah tersebut, salah satu solusi teknologi yang dapat diterapkan adalah dengan menggunakan air limbah rumah tangga untuk di recycle sehingga dapat digunakan kembali dalam pertanian di daerah urban. Menurut Direktur Pengembangan Air Minum Poejastanto, Ditjen Cipta Karya Pemakaian air rata-rata rumah tangga di perkotaan di Indonesia sebesar setiap orang 144 liter perharinya. Pemakaian terbesar adalah untuk keperluan mandi sebesar 60 liter perhari perorang atau 45 persen dari total pemakaian air. Jumlah yang cukup besar untuk dapat dimanfaatkan dengan bantuan teknologi sehingga meminimalkan jumlah air yang terbuang dan dapat dimanfaatkan untuk kebutuhan lainnya atau biasa disebut dengan reuse water yang merupakan sistem pemanfaatan air buangan dari proses waste water treatment. dimana air tersebut di treatment kembali dengan menggunakan Ultrafiltrasi, hingga dapat memenuhi standar air bersih,.air dapat di gunakan kembali ke berbagai kebutuhan sehingga dapat menghemat penggunaan air sehingga penggunaan air dari sumber air seperti tanah dan PDAM dapat terkontrol dan merata kepada seluruh lapisan masyarakat, sumber air lain yang dapat dimanfaatkan adalah air hujan dan air sungai yang saat ini masih belum termanfaatkan secara maksimal, dengan bantuan teknologi IT sumber air alternatif ini juga bisa digunakan dalam membantu kebutuhan urban farming dengan konsep smart water management system sehingga biaya untuk menyedikan air dapat di pangkas se-efektif dan efisien mungkin, selain itu penggunaan air hujan bisa menjadi solusi dalam menyelesaikan masalah air yang dihadapi pertanian urban, hujan menyediakan air gratis untuk berbagai keperluan, termasuk irigasi. tangkapan air hujan menghadirkan potensi besar untuk penghematan air, mengurangi ketergantungan pada air PDAM atau air tanah.

Konsep "Smart" dalam smart water management (SWM) yang akan dibangun dapat dimaksudkan bahwa kerangka kerja ini mampu membuat penggunaan air terkelola secara efektif dan efisien, Tantangan lain juga termasuk menyediakan air berkualitas dengan biaya minimum. SWM dapat membawa perubahan dalam hal mendapatkan data melalui teknologi Internet-of-things secara realtime sehingga dapat dilakukan analisis dalam waktu yang cepat dalam menggambil keputusan pengelollan air untuk memperkecil biaya yang harus dikeluarkan di masa yang akan datang menggunakan metode machine learning, Sistem SWM yang diusulkan dibangun mencakup pemantauan tingkat air secara realtime, mengidentifikasi kebocoran dalam sistem distribusi air melalui pipa, serta memantau dan menjaga kualitas air selain itu seluruh data serta hasil analisis dapat diakses melalui perangkat bergerak seperti smartphone. Meskipun penelitian tentang SWM sedang 
dipercepat untuk memenuhi permintaan industri dan pemerintah, kesenjangan konseptual, teknis dan praktis antara penyedia dan klien masih belum dijembatani dengan baik. Pengaruh SWM bisa menjadi lebih signifikan dan penting jika prioritas didefinisikan secara tepat dan diimplementasika domain teknologi dalam konteks pengelolaan air.

Ada berbagai arsitektur yang diusulkan oleh penulis yang berbeda berdasarkan jenis dan tingkat keamanan yang diperlukan oleh setiap aplikasi. Arsitektur enam layer telah diusulkan dalam [2] dengan menggabungkan layanan Web, RFID dan WSN sedangkan arsitektur lima level telah disebutkan dalam [4] berdasarkan jaringan manajemen telekomunikasi. Arsitektur dasar dan sederhana [3] terdiri dari tiga lapisan yaitu persepsi, jaringan dan lapisan aplikasi. Arsitektur ini akan digunakan dalam makalah ulasan yang berfokus pada SWM. Arsitektur dasar three tier untuk Internet of Things dibahas dalam [5]. Tingkat bawah terdiri dari berbagai 'things' atau 'benda' seperti sensor, ponsel, aktuator, dll. Middle tier adalah tier jaringan yang dapat berupa nirkabel atau kabel untuk transfer informasi yang dihasilkan / dikumpulkan oleh 'things' dengan andal. layer aplikasi adalah layer atas tempat data diproses, dianalisis, dan tersedia bagi pengguna akhir sebagai pengetahuan dari informasi. Berbagai teknologi seperti RFID, sensor nirkabel, skema pengalamatan dll yang dapat digunakan dalam mengimplementasikan IoT telah dibahas dan studi perbandingan tentang berbagai teknologi nirkabel seperti Bluetooth, Wi-Fi dan XBee dibuat dalam [6]. Sedangkan dalam kerangka kerja yang kami usulkan menambahkan kemampuan dalam mengelola air limbah rumah tangga dan air hujan dalam mendukung kebutuhan air terhadap pertanian urban.

\section{KERANGKA KERJA YANG DIUSULKAN}

Sesuai dengan karakteristik smart water, kami mengusulkan kerangka kerja Smart Water Management (SWM) system untuk mendukung urban farming yang ditunjukkan pada Gambar 1. Berikut:

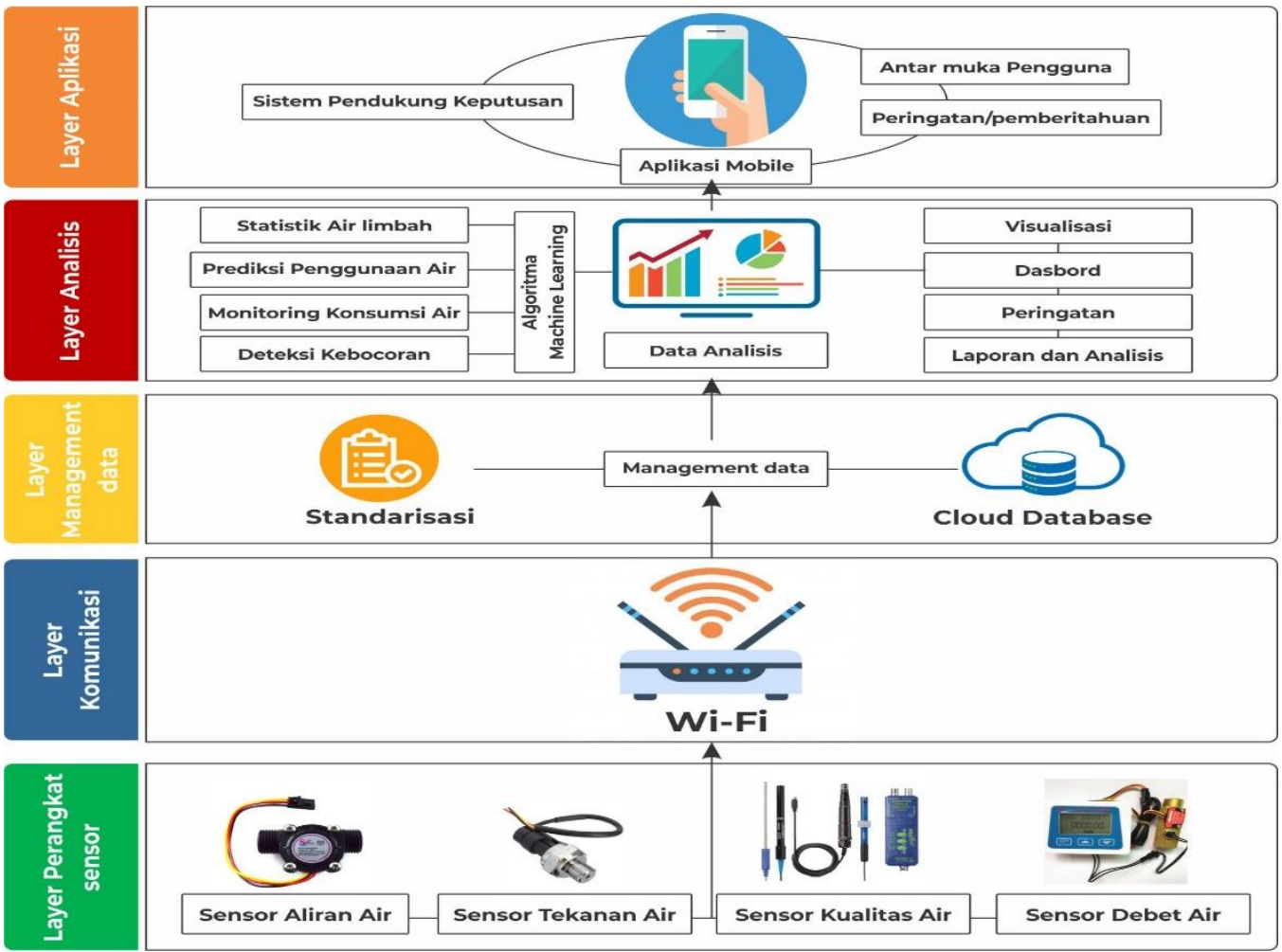

Gambar 1. Gambaran umum kerangka kerja Smart Water Management 
Ada lima komponen utama dari kerangka kerja Smart Water Management yang kami usulkan antara lain:

1. Layer 1 Perangkat sensor

Pada layer ini seluruh perangkat sensor dikelola dan digunakan untuk menangkap informasi dan data yang dibutukan secara realtime dan berkala, data yang diakuisisi dan dimonitoring untuk di kirim kepusat data melalui layer komunikasi

2. Layer 2 Komunikasi dengan konektivitas melalui Wi-Fi dapat digunakan sebagai penghubung antara perangkat sensor menuju pusat data untuk dapat mulai diproses, perangkat nirakabel digunakan dengan tujuan mempermudah mobilitas system dalam mengirim data kepusat data.

3. Layer 3 Management data

Pada layer ini menyimpan dan mengelola data volume besar yang dikumpulkan dari sensor. Selain itu, ini berfungsi sebagai titik standardisasi tempat data yang dikumpulkan akan diproses sehingga data akan distandarisasi dengan domain data sektor smart water management

4. Layer 4 Analisis

Layer ini menyediakan fungsi dukungan operasi data, manajemen keamanan aplikasi, manajemen alur kerja, pertukaran dan berbagi data, pemodelan dan simulasi sistem air serta visualisasi hasil analisis. Proses menghasilkan atau menangkap data perlu dikelola dan dipantau, referensi data, bagaimana mereka dibagi dalam sistem informasi harus didefinisikan serta pengelolaan data dengan menggunakan algoritma machine learning untuk memodelkan system yang dapat beradaptasi terhadap kondisi lingkungan.

5. Layer 5 Aplikasi

Layer ini didukung antar muka yang integrate dan tersedia pada perangkat bergerak (mobile) dengan sistem pendukung keputusan di mana keputusan optimisasi dan langkahlangkah manajemen diambil dari analisis pekerjaan yang dilakukan dalam layer analisis. Contohnya termasuk pengaturan cerdas dan optimalisasi kualitas dan kuantitas air, efisiensi pengiriman layanan kerja yang diperlukan dan peringatan dini akan kekurangan air atau luapan air, serta penglolaan terhadap air yang digunakan pada pertanian urban ataupun perkebunan.

\section{HASIL DAN PEMBAHASAN}

Meskipun kerangka kerja konseptual yang kami usulkan belum diuji di lapangan, kami berharap dapat memberikan panduan bagi para pengguna dalam mereplikasi Smart Water Management sesuai dengan tujuan dan aplikasinya masing-masing, salah satu implementasi yang dapat dilakukan adalah penggunaan rumahan yang memiliki kapasitas yang kecil dan sangat mudah diterapkan, kami gambarkan pada Gambar 2 berikut : 


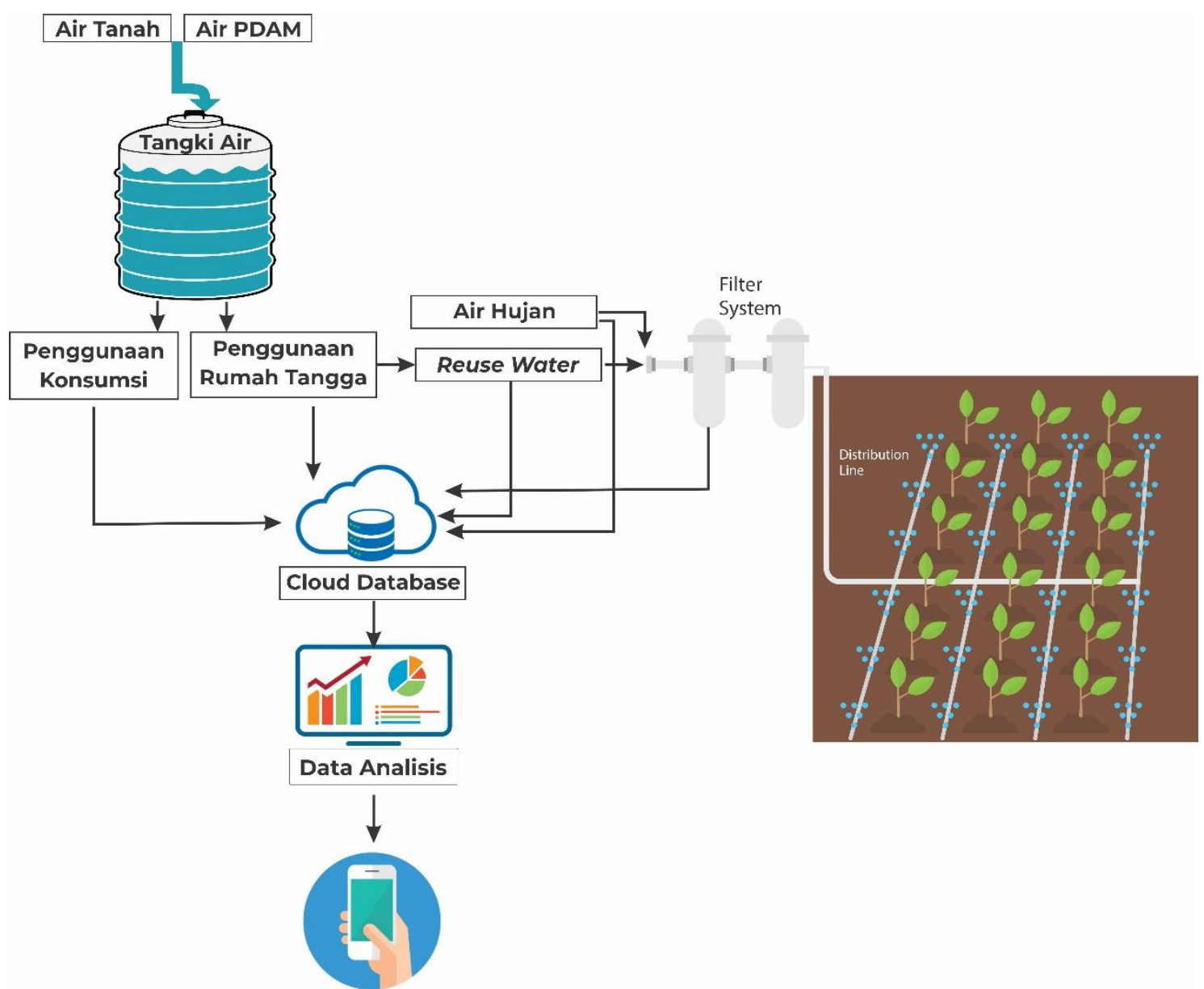

Gambar 2. Desain penerapan Smart Water Management system untuk pertanian urban

Dalam model pertanian tradisional data penggunaan air belum tercatat dengan baik sehingga perkiraan kebutuhan air menjadi satu hal yang penting, agar kerangka kerja dapat menyiapkan sumber daya air yang cukup untuk memenuhi seluruh kebutuhan, baik itu bersumber dari air tanah maupun air limbah yang sudah diolah dan difilterisasi sehingga memenuhi standar kualitas air yang dibutuhkan tumbuhan untuk pertanian, sebagaimana pemenuhan sumber daya air untuk pertanian, analisis kebutuhan dan pengukuran debet air yang tersedia dipenampungan dapat menjadi kelebihan dari kerangka kerja smart water management yang kami tawarkan sehingga dapat mengontrol ketersediaan air dan dapat memberikan peringatan atau pemberitahuan dini pada musim kering maupun jika terdapat kebocoran pada saluran distribusi air. Terakhir dengan bantuan algoritma machine learning kerangka kerja dapat berjalan secara automation dalam memprediksi kebutuhan air di masa yang akan datang.

\section{KESIMPULAN DAN SARAN}

Pembangunan Smart Water Management System adalah proses jangka panjang yang sistematis dengan tujuan dapat mengontrol penggunaan air secara efektif dan efesien sehingga tidak ada air yang terbuang baik yang sudah merupakan limbah rumah tangga dapat diolah sehingga dapat dimanfaatkan kembali khususnya dalam bidang pertanian urban sebagai pendukung berkaitan dengan keterbatasan sumber daya air diperkotaan serta harganya yang mahal sehingga perlu ada kerangka kerja yang dapat memanfaatkan sumber daya air yang belum terpakai secara maksimal. 
Masih banyak teknologi yang bisa dilengkapi di kerangka kerja Smart Water Management System salah satunya terkait dengan penggunaan algoritma machine learning dalam penentuan atau pemilihan sumber daya air yang akan digunakan dalam pengairan lahan pertanian melihat dari cuaca, musim ataupun ketersediaan air dalam tangki air yang tersedia.

\section{UCAPAN TERIMAKASIH}

Penulis mengucapkan terima kasih kepada Instansi/perusahaan/lembaga yang telah memberi dukungan yang membantu pelaksanaan penelitian dan atau penulisan artikel.

\section{DAFTAR PUSTAKA}

[1] Kamienski Carlos, Juha-Pekka Soininen, Markus Taumberger, Ramide Dantas, Attilio Toscano, , Tullio Salmon Cinotti, Rodrigo Filev Maia \& André Torre Neto, "Smart Water Management Platform: IoT-Based Precision Irrigation for Agriculture", Sensors 2019, 19, 276; doi:10.3390/s19020276

[2] J.M.P. Martinez, R.B. Llavori, M.J.A. Cabo, and T.B. Pedersen, "Integrating Data Warehouses with Web Data: A Survey," IEEE Trans. Knowledge and Data Eng., preprint, 21 Dec. 2007, doi:10.1109/TKDE.2007.190746.

[3] M. Zhang, F. Sun and X. Cheng, "Architecture of Internet of Things and Its Key Technology Integration Based-On RFID”, Proc IEEE Fifth International Symp. on computational intelligence and design, Oct. 2012, doi:10.1109/ISCID.2012.81.

[4] J. Lin, W. Yu, N. Zhang, X. Yang, H. Zhang, W. Zhao, "A survey on internet of things: Architecture enabling technologies security and privacy and applications", IEEE Internet of Things Journal, vol.4 (5), pp. 1125-1142, Oct. 2017.

[5] Prajakta Pande , Anand R. Padwalkar2 , "Internet of Things -A Future of Internet: A Survey," International Journal of Advance Research in Computer Science and Management Studies, Volume 2, Issue 2, February 2014

[6] 5. A. Kumar, K. Kamal, M. O. Arshad, T. Vadamala, S. Mathavan,"Smart Irrigation Using Low-Cost Moisture Sensors and XBee-based Communication," in IEEE 2014 Global Humanitarian Technology Conference, 2014.

[7] Lian Guey Ler, Philippe Gourbesville, "Framework Implementation for Smart Water Management", EPiC Series in Engineering, Volume3, 2018,Pages 1139-1146, HIC 2018.13th International Conference on Hydro informatics

[8] Jiada Li, Xiafei Yang and Robert Sitzenfrei, "Rethinking the Framework of Smart Water System: A Review", Water 2020, 12, 412; doi:10.3390/w12020412

[9] Mohammed Shahanas.Ka, Dr.Bagavathi Sivakumar P.b, "Framework for a smart water management system in the context of smart city initiatives in India", 2nd International Conference on Intelligent Computing, Communication \& Convergence (ICCC-2016)

[10] Wang Yuanyuana, Liu Pingb, Shi Wenzec, Yin Xinchun, “A New Framework on Regional Smart Water", International Congress of Information and Communication Technology (ICICT 2017)

[11] M. Safdar Munir, Imran Sarwar Bajwa, Sehrish Munawar Cheema, "An intelligent and secure smart watering system using fuzzy logic and blockchain", Computers and Electrical Engineering 77 (2019) 109-119

[12] J. J. Daniel et al., "Implementation of a novel SCADA architecture for a $210 \mathrm{MW}$ thermal power plant,” Proc. - 2014 Int. Conf. Data Sci. Eng. ICDSE 2014, pp. 182-187, 2014. 
[13] 5. K. Kumar, "Monitoring and Controlling Tap Water Flow at Homes Using Android Mobile Application,” Am. J. Softw. Eng. Appl., vol. 6, no. 6, p. 128, 2017.

[14] P. Hohenblum, "Workshop on early warning systems" (2014). Report of ERNCIP thematic area Chemical \& Biological Risks in the Water Sector Deliverable D1 -Task 1. Retrieved from https://erncipproject.

jrc.ec.europa.eu/sites/default/files/Review_of_sensors_to_monitor_water_ quality.pdf, 26 Jun. 2014.

[15] K. Abhirami and L.R. Karlmarx. "A novel fault-tolerant control scheme for water distribution systems", Proc. IEEE Conference on Energy Efficient Technologies for Sustainability, Apr. 2013, doi: 10.1109/ICEETS.2013.6533496.

[16] T. P. Lambrou, C. C. Anastasiou, C. G. Panayiotou and M. M. Polycarpou, "A Low-Cost Sensor Network for Real-Time Monitoring and Contamination Detection in Drinking Water Distribution Systems". IEEE Sensors Journal, 14(8), 2765-2772, 2014.

[17] Varsha Radhakrishnan and Wenyan Wu, "IoT technology for Smart water system" 2018 IEEE 20th International Conference on High Performance Computing and Communications; IEEE 16th International Conference on Smart City; IEEE 4th Intl. Conference on Data Science and Systems 